\title{
The cannabinoid agonist CB-13 produces peripherally mediated analgesia in mice but elicits tolerance and signs of CNS activity with repeated dosing
}

Richard A. Slivicki ${ }^{1}$, Jiwon $\mathrm{Yi}^{1}{ }^{1,2}$, Victoria E. Brings ${ }^{1}$, Phuong Nhu Huynh ${ }^{1}$ and Robert W. Gereau

$$
\mathrm{IV}^{1,3,4} \text {. }
$$

${ }^{1}$ Washington University Pain Center and Department of Anesthesiology, Washington University School of Medicine, St. Louis, MO.

${ }^{2}$ Neuroscience Graduate Program, Division of Biology \& Biomedical Sciences, Washington University School of Medicine, St. Louis, MO.

${ }^{3}$ Department of Neuroscience, Washington University, St. Louis, MO

${ }^{4}$ Department of Biomedical Engineering, Washington University, St. Louis, MO

Corresponding author: Robert W. Gereau IV, Washington University Pain Center, Department of Anesthesiology, Washington University School of Medicine, St. Louis, MO.

email:gereaur@wustl.edu 
bioRxiv preprint doi: https://doi.org/10.1101/2021.04.23.441212; this version posted April 26, 2021. The copyright holder for this preprint (which was not certified by peer review) is the author/funder. All rights reserved. No reuse allowed without permission.

\section{Conflict of Interest Statement}

The authors declare no conflict of interest. 


\section{Abstract}

Activation of cannabinoid receptor type $1\left(\mathrm{CB}_{1}\right)$ produces analgesia in a variety of preclinical models of pain; however, engagement of central $\mathrm{CB}_{1}$ receptors is accompanied by unwanted side effects, such as tolerance and dependence. Efforts to develop novel analgesics have focused on targeting peripheral $\mathrm{CB}_{1}$ receptors to circumvent central $\mathrm{CB}_{1}$-related side effects. In the present study, we evaluated the effects of acute and repeated dosing with the peripherally selective $\mathrm{CB}_{1}$-preferring agonist $\mathrm{CB}-13$ on nociception and central $\mathrm{CB}_{1}$-related phenotypes in an inflammatory model of pain in mice. We also evaluated cellular mechanisms underlying CB-13induced antinociception in vitro using cultured mouse dorsal root ganglion (DRG) neurons. CB13 reduced inflammation-induced mechanical allodynia in a peripheral $\mathrm{CB}_{1}$ receptor-dependent manner and relieved inflammatory thermal hyperalgesia. In cultured mouse DRG neurons, CB13 reduced TRPV1 sensitization and neuronal hyperexcitability induced by the inflammatory mediator prostaglandin E2, providing potential mechanistic explanations for the analgesic actions of peripheral $\mathrm{CB}_{1}$ receptor activation. With acute dosing, phenotypes associated with central $C B_{1}$ receptor activation occurred only at a dose of $C B-13$ approximately 10 -fold the $E D_{50}$ for reducing allodynia. Strikingly, repeated dosing resulted in both analgesic tolerance and $\mathrm{CB}_{1}$ receptor dependence, even at a dose that did not produce central $\mathrm{CB}_{1}$ receptor-mediated phenotypes on acute dosing. This suggests repeated CB-13 dosing leads to increased CNS exposure and unwanted engagement of central $\mathrm{CB}_{1}$ receptors. Thus, caution is warranted regarding therapeutic use of CB-13 with the goal of avoiding CNS side effects. Nonetheless, the clear analgesic effect of acute peripheral $\mathrm{CB}_{1}$ receptor activation suggests that peripherally restricted cannabinoids are a viable target for novel analgesic development. 


\section{Introduction}

Chronic pain impacts $11.2 \%$ of individuals nationwide[53] and current pharmacotherapies for the treatment of chronic pain produce significant unfavorable effects including tolerance and dependence. The U.S. is currently in the midst of an opioid epidemic that is driven in part by opioids prescribed for pain relief [37]. Thus, there is an urgent need to develop safer, more effective therapies for the treatment of chronic pain. A large body of preclinical evidence supports the use of cannabinoids as pain-relieving pharmacotherapies in rodent models of neuropathic, inflammatory and visceral pain $[2,77]$. This mirrors some clinical reports showing vaporized or smoked cannabis is effective at treating different types of chronic pain [31]. However, a recent IASP task force [1] concluded that the current evidence base is insufficient to endorse the use of cannabis for the clinical management of pain, and called for "more rigorous and robust research to better understand any potential benefits and harms." Cannabis-based therapies are not always efficacious and can possess unwanted side effects, including tolerance and psychoactivity [55]. Such centrally mediated side effects may limit therapeutic use by prevent adequate dosing to produce a peripherally mediated analgesic effect. Furthermore, it is important to note that $\Delta^{9}$-THC, the primary active ingredient in the cannabis-based therapies tested in clinical trials, is a partial agonist at $\mathrm{CB}_{1}$ receptors $[59,67]$. Thus, it possible that full activation of peripheral $\mathrm{CB}_{1}$ receptors could produce more robust analgesia in clinical trials than cannabis-based treatments have shown to date while also avoiding centrally mediated side effects. Therefore, considerable interest remains in developing peripherally restricted cannabinoid receptor agonists for pain and other indications, building on prior evidence supporting the use of cannabis-based medicines for the treatment of pain.

Cannabinoids exert their effects through engagement of cannabinoid receptors, which include cannabinoid type-1 $\left(\mathrm{CB}_{1}\right)$ and type-2 $\left(\mathrm{CB}_{2}\right)$ receptors. In particular, $\mathrm{CB}_{1}$ receptor engagement has been demonstrated to reduce pain-related behaviors in a number of animal models [77]. 
Activation of $\mathrm{CB}_{1}$ receptors in the central nervous system also results in psychoactivity in humans and typical "tetrad" behaviors in rodents (catalepsy, hypothermia, motor ataxia and antinociception[44]). Thus, utilizing $\mathrm{CB}_{1}$ receptor signaling in a manner that provides analgesia while avoiding such side effects would be ideal for therapeutic use.

There are many potential sites of analgesic action for $\mathrm{CB}_{1}$ receptor activation, as these receptors are expressed abundantly throughout the central and peripheral nervous systems[30,32,33,77]. Many studies show analgesic effects of peripheral $\mathrm{CB}_{1}$ activation. Peripheral administration of cannabinoid agonists leads to reductions of neuropathic allodynia[22,52], and inhibition of the endocannabinoid degradative enzyme fatty-acid amide hydrolase in the periphery results in peripheral $C_{1}$ receptor-mediated reductions in nociceptivelike behaviors in inflammatory and neuropathic pain models $[7,68]$. Deletion of $\mathrm{CB}_{1}$ receptors from primary sensory neurons leads to a loss of antinociceptive efficacy of WIN55,212-2 (a centrally penetrant pan-cannabinoid agonist [11]), while typical behaviors reflective of central $\mathrm{CB}_{1}$ engagement (e.g. catalepsy) are conserved [3]. Thus, targeting peripheral $\mathrm{CB}_{1}$ receptors may conserve analgesic efficacy while circumventing unwanted side effects associated with engagement of central $\mathrm{CB}_{1}$ receptors. Drug discovery efforts have therefore focused on designing peripherally restricted $\mathrm{CB}_{1}$ receptor-preferring ligands. Indeed, peripherally restricted cannabinoid agonists reduce nociceptive-like behaviors in models of neuropathic $[22,81,83]$, inflammatory $[21,81]$ and headache [78] pain when administered acutely. Many of the aforementioned studies, however, do not include pharmacological or genetic control conditions to ensure the analgesic effects of such compounds are mediated by peripheral $\mathrm{CB}_{1}$ receptors. Further, consequences of long-term, repeated administration of such compounds on both centrally mediated behaviors and antinociception remain poorly understood.

The present study sought to evaluate the peripherally selective $C_{1}$ receptor-preferring agonist CB-13[22] in both male and female mice using a model of inflammatory pain induced by 
Freund's complete adjuvant (CFA), as this model has previously been shown to be unresponsive to $\mathrm{CB}_{2}$ agonists in mice [41]. We also assessed the impact of repeated administration of CB-13 on therapeutic tolerance and the cannabinoid 'triad' (catalepsy, antinociception, hypothermia) in CFA-treated and naïve animals, respectively. Finally, we evaluated the ability of CB-13 to reduce prostaglandin E2 (PGE2)-induced TRPV1 sensitization and alterations in neuronal excitability as potential mechanistic links to CB-13's analgesic efficacy.

\section{Methods:}

\section{Subjects}

All experiments used C57BL/6J mice purchased from Jackson Laboratory (Bar Harbor, ME) or bred in-house. Mice were 8-9 weeks of age at the start of behavioral experiments and 6-8 weeks of age for calcium imaging and electrophysiology experiments [66]. Animals were group housed with 3-5 animals per cage and were maintained in a temperature-controlled facility with ad libitum food and water and maintained on a 12-hour light-dark cycle (lights on at 07:00 hr19:00 hr). All experimental procedures were approved by the Washington University Animal Care and Use Committee and followed the guidelines of the Internal Association for the Study of Pain. Mice were randomly assigned to experimental conditions.

\section{Drugs and chemicals}

Freund's complete adjuvant (CFA) (Thermo Fisher, St. Louis, MO) was dissolved in a 1:1 ratio of saline:CFA prior to intraplantar (i.pl) injection. CB-13, AM6545 and rimonabant (all from Cayman Chemical Company, Ann Arbor, MI) were dissolved in vehicle consisting of 20\% DMSO (Sigma Aldrich, St. Louis, MO), 8\% ethanol, 8\% 1Tween 80 (Thermo Fisher, St. Louis, MO) and $64 \%$ saline and administered via intraperitoneal (i.p.) injection in a volume of $5 \mathrm{~mL} / \mathrm{kg}$ for behavioral studies. CB-13 and rimonabant were dissolved in DMSO (25 mg/mL) and frozen until 
use. On the day of the experiment, stocks were diluted with a volume of DMSO to achieve a concentration of $20 \%$ DMSO in the final solution. $95 \%$ ethanol was then added, the solution vortexed again, followed by Tween 80 and finally saline. For AM6545, the steps were the same as the other compounds used, but the solution was sonicated for approximately 45 minutes to get the compound to fully dissolve (when the solution was clear). For calcium imaging and electrophysiology studies, prostaglandin E2 (PGE2) (Thermo Fisher, St. Louis, MO) and CB-13 were dissolved in DMSO and diluted in external recording solution.

\section{Allodynia measurements}

Mechanical allodynia was evaluated using an electronic von Frey anesthesiometer (IITC Life Science, model Alemo 2390-5, Woodland Hills, CA) as described previously [19,28,68,69]. In brief, animals were habituated to $10 \mathrm{~cm} \times 10 \mathrm{~cm}$ acrylic holding containers placed on an elevated mesh platform $1 \mathrm{~h}$ prior to testing. Black dividers prevented mice from seeing other mice being tested simultaneously. Pressure was applied to the plantar surface of the hindpaw using the anesthesiometer, and the maximum force applied before the animal withdrew its paw was recorded. Each paw was stimulated twice with at least $7 \mathrm{~min}$ between stimulations. The two withdrawal thresholds were averaged for each data point.

Responsivity to heat stimulation was measured using a thermal plantar test apparatus (IITC Life Science, model 390) as described previously[5]. In brief, animals were habituated on a glass surface heated to $30^{\circ} \mathrm{C}$ in the same acrylic containers with black dividers as used for mechanical allodynia. A focused beam of light was applied to the hindpaw, and the latency for the animal to withdraw its paw was recorded. Each hindpaw of the animal was tested 2-3 times with at least 5 min between each measurement. A cutoff latency of 20 s per stimulation was applied to avoid tissue damage. The withdrawal latencies for all stimulations on a single paw were averaged for each data point. 


\section{CFA-induced allodynia}

CFA has been widely used to model allodynic responses following an inflammatory insult [48]. To induce CFA-induced injury, on the same day as baseline values were recorded, a $20 \mu \mathrm{L}$ injection of 1:1 CFA:saline was administered via unilateral i.pl. injection in the hindpaw with a 28.5-gauge needle[69]. Approximately $18 \mathrm{~h}$ following CFA injection, post-CFA values for responsiveness to mechanical and heat stimulation were assessed.

\section{Dose-response studies}

Within-subjects dose-response curves were generated to evaluate the ability of CB-13 to reduce CFA-induced mechanical allodynia as described previously[68,69]. CB-13 $(0.3,1,3,10 \mathrm{mg} / \mathrm{kg}$ i.p.) or vehicle was administered in spate cohorts of male and female mice starting approximately $20 \mathrm{~h}$ after CFA injection allowing at least $24 \mathrm{~h}$ between escalating doses. Mechanical thresholds were evaluated prior to CB-13 or vehicle injection and 30 min following injection of the assigned drug condition.

\section{Timecourse and chronic dosing studies}

In hourly timecourse experiments, animals were evaluated for mechanical or heat hypersensitivity (using separate cohorts for each modality) at baseline and $18 \mathrm{~h}$ following CFA injection. Immediately after post-CFA thresholds were measured, animals were injected with either vehicle or CB-13 (1, 3, $10 \mathrm{mg} / \mathrm{kg}$ i.p.) and then evaluated again for responsivity to mechanical $(0,0.5,1,1.5,6,7.5$, and $24 \mathrm{~h})$ or heat $(0,0.5,1,1.5,2,5,7.5$, and $24 \mathrm{~h})$ stimulation. Doses were chosen based on dose-response response studies and previous reports. A low but effective dose (1 $\mathrm{mg} / \mathrm{kg}$ i.p.) [8], a maximally effective but peripherally restricted dose (3 mg/kg i.p.) [60,61] and a high but likely CNS-penetrant dose (10 mg/kg i.p.) [60] were incorporated to better understand the interplay between peripheral and central activation of $\mathrm{CB}_{1}$ receptors in relation to anti-allodynic effects and tolerance development. 
For chronic dosing studies, the same animals tested in the mechanical hypersensitivity hourly timecourse were administered the assigned treatment once daily at $\sim 10: 00 \mathrm{~h}$. Animals were evaluated for mechanical thresholds prior to and 30 min post injection on days 1, 3 and 7. Chronic dosing was not evaluated for heat hypersensitivity as our studies indicated that thresholds returned to baseline values $\sim 26 \mathrm{~h}$ after CFA injection (Figure 4E).

\section{Pharmacological specificity}

In CFA-injected animals, the peripherally restricted $\mathrm{CB}_{1}$ receptor antagonist AM6545 (10 mg/kg i.p.)[9] was administered $30 \mathrm{~min}$ prior to administration of $\mathrm{CB}-13$ (3 $\mathrm{mg} / \mathrm{kg}$ i.p.), or $60 \mathrm{~min}$ prior to testing. Animals were tested at 30 min following CB-13 injection, as this is the timepoint at which the reversal of allodynia was deemed to be maximal based on the timecourse studies (Figure $1 \mathrm{E})$.

\section{Cannabinoid triad}

Centrally penetrant $\mathrm{CB}_{1}$ receptor agonists induce a classical "tetrad" of behavioral effects in mice which include catalepsy, locomotor ataxia, antinociception and hypothermia[44]. We examined, in order, catalepsy, tail-flick antinociception and hypothermia at several different timepoints. Animals were dosed once daily with either vehicle or CB-13 (3 or $10 \mathrm{mg} / \mathrm{kg}$ i.p.). Triad measures were taken at several times (just prior to dosing and 0.5, 1, 1.5, 3, 6, 7.5 and 24 h post-drug) on days 1, 3 and 7 to mimic chronic dosing studies in the CFA condition.

\section{Evaluation of $\mathrm{CB}_{1}$ receptor-mediated dependence}

$\mathrm{CB}_{1}$ receptor dependence is commonly evaluated via administration of the $\mathrm{CB}_{1}$ antagonist rimonabant to precipitate somatic withdrawal in animals chronically treated with a $\mathrm{CB}_{1}$ agonist[42,43]. In chronic dosing studies, mice were dosed daily with CB-13 or vehicle for 9 days, and on the $9^{\text {th }}$ day rimonabant $(10 \mathrm{mg} / \mathrm{kg}$ i.p.) was administered $1 \mathrm{~h}$ following a final injection of CB-13 or vehicle, and animals were video recorded for $30 \mathrm{~min}$. The number of 
rimonabant-evoked scratching behaviors and paw tremors were manually evaluated using Behavioral Observation Research Interactive Software (BORIS)[24].

\section{Mouse DRG cultures}

For each tissue preparation, mice were euthanized via induction of isoflurane briefly followed by decapitation. The spinal column was removed and bisected; lumbar DRG were removed and pooled, and subjected to enzymatic incubations as described $[16,45,66]$. DRG tissue was incubated in papain (45 $\mathrm{U}$ in $\mathrm{HBSS}+\mathrm{H}$, Worthington) for $20 \mathrm{~min}$ at $37^{\circ} \mathrm{C}$, rinsed, and incubated in collagenase $(1.5 \mathrm{mg} / \mathrm{mL}$ in $\mathrm{HBSS}+\mathrm{H}$, Sigma-Aldrich) for $20 \mathrm{~min}$. DRG were washed again with $\mathrm{HBSS}+\mathrm{H}$, then transferred to $1 \mathrm{~mL}$ of DRG media which consisted of Neurobasal A medium (Invitrogen) supplemented with $100 \mathrm{U} / \mathrm{mL}$ penicillin/streptomycin (Corning), 2 mM GlutaMAX (Life Technologies), 2\% B27 (Gibco), and 5\% fetal bovine serum (Gibco). DRG were then manually triturated with fire-polished Pasteur pipettes (VWR) and passed through a $40-\mu \mathrm{m}$ filter (VWR). DRG were then plated onto poly-d-lysine/collagen (Sigma-Aldrich)-coated 12-mm glass coverslips (Thermo Fisher Scientific) and stored at $37^{\circ} \mathrm{C}$ and $5 \% \mathrm{CO}_{2}$ until testing.

\section{Calcium imaging}

Calcium imaging studies were performed the day after plating. Cultured neurons were incubated with $3 \mu \mathrm{g} / \mathrm{mL}$ of the ratiometric calcium indicator Fura-2 AM (Life Technologies) in external recording solution for $30 \mathrm{~min}$ at $37^{\circ} \mathrm{C}$ and $5 \% \mathrm{CO}_{2}$. To evaluate the impact of $\mathrm{CB}_{1}$ receptor activation on TRPV1 sensitization, we utilized a protocol that assesses the ability of inflammatory mediators to potentiate capsaicin-induced calcium influx in cultured DRG neurons, as demonstrated and described in previous publications [66]. Coverslips were then transferred to a recording chamber and continuously perfused at room temperature with external recording solution, containing the following (in $\mathrm{mM}$ ): $130 \mathrm{NaCl}, 5 \mathrm{KCl}, 2 \mathrm{CaCl}_{2}, 1 \mathrm{MgCl}_{2}, 30$ glucose, and 10 HEPES. Cells were visualized under an inverted microscope (Olympus Optical), and 
fluorescent images were acquired every 2 s using a Hamamatsu ORCA camera (Hamamatsu) and SimplePCI Software (HCImage, Hamamatsu). Fura-2 AM fluorescence intensity was recorded using alternating excitation wavelengths of 357 and $380 \mathrm{~nm}$. The experimental timeline was as follows: 2 min baseline (external solution), 20s application of $200 \mathrm{nM}$ of capsaicin, 3 min wash with external solution, 11 min of drug treatment (1 of 3 conditions, follows), a second pulse of $200 \mathrm{nM}$ of capsaicin was applied for 20 s followed by a 4 min wash (external solution), then a 10s pulse of $\mathrm{KCl}(50 \mathrm{mM})$ was applied to evaluate for cell viability. The three drug treatment conditions were $11 \mathrm{~min}$ of vehicle, $1 \mathrm{~min}$ of vehicle followed by $10 \mathrm{~min}$ of $1 \mu \mathrm{M}$ PGE2, or $1 \mathrm{~min}$ of $1 \mu \mathrm{M}$ CB-13 followed by 10 min of $1 \mu \mathrm{M}$ PGE2 + $1 \mu \mathrm{M}$ CB-13. Each coverslip was tested with one treatment condition, and 2-3 treatment conditions were evaluated for each mouse preparation. Cells that did not return to within $10 \%$ of their baseline values after the first capsaicin application, or did not respond to $\mathrm{KCl}$ application, were excluded from further analysis.

\section{Electrophysiology}

Electrophysiology experiments were conducted 1-2 days following plating. Primary DRG neurons were transferred to a recording chamber and perfused with external recording solution containing the following (in $\mathrm{mM}$ ): $145 \mathrm{NaCl}, 3 \mathrm{KCl}, 2 \mathrm{CaCl}_{2}, 1 \mathrm{MgCl}_{2}, 7$ glucose, $10 \mathrm{HEPES}$. Whole-cell patch-clamp recordings were made using fire-polished borosilicate glass pipettes with 3-6 $\mathrm{M} \Omega$ resistance. The pipettes were filled with $\mathrm{KCl}$-based internal solution consisting of the following (in $\mathrm{mM}$ ): $120 \mathrm{~K}$-gluconate, $5 \mathrm{NaCl}, 3 \mathrm{MgCl}_{2}, 0.1 \mathrm{CaCl}_{2}, 10 \mathrm{HEPES}, 1.1 \mathrm{EGTA}, 4$ $\mathrm{Na}_{2}$ ATP, $0.4 \mathrm{Na}_{2} \mathrm{GTP}, 15 \mathrm{Na}_{2}$ Phosphocreatine; adjusted to $\mathrm{pH} 7.3$ with $\mathrm{KOH}$ and $\mathrm{HCl}$, and 290 mOsm with sucrose. For some of the recordings, the internal solution also contained $50 \mu \mathrm{M}$ Alexa Fluor 568 (Invitrogen). All experiments were conducted at room temperature. Recordings were made using a MultiClamp 800B amplifier and a Digidata 1550B digitizer (Molecular Devices, CA). Only smaller neurons with a diameter $<24 \mu \mathrm{m}$ were studied $(19.0 \pm 2.3 \mu \mathrm{m}$, average $\pm S D$ ). Series resistance was kept below $15 \mathrm{M} \Omega$ in all recordings. After a stable whole- 
cell configuration was achieved, membrane excitability was assessed in current-clamp mode. All recordings were done at the resting membrane potential of each cell $(-53.6 \pm 7.1 \mathrm{mV}$ at baseline, average \pm SD). For all experiments, membrane excitability was assessed before ("pretreatment") and after drug treatment (1 $\mu \mathrm{M}$ PGE2, $1 \mu \mathrm{M}$ CB-13, $1 \mu \mathrm{M}$ CB-13 + $1 \mu \mathrm{M}$ PGE2, or $0.1 \%$ DMSO). In a subset of CB-13 experiments ( $n=5$ cells), cells were additionally treated with both the CB-13 + PGE2 condition following the CB-13 incubation. There was no significant difference in membrane excitability during CB-13 + PGE2 treatment between cells that were pre-treated with CB-13 and cells that were not.

Resting membrane potential was monitored during drug application and throughout the experiment; if any cell's resting membrane potential depolarized $>-40 \mathrm{mV}$, the experiment was discarded or excluded from analysis. Electrophysiology data were compiled using ClampFit (v.11.1, Molecular Devices). Input-output relationship was determined by counting the number of action potentials generated by 1 second current steps in 10 pA increments from 0 to 300 pA. To account for the heterogeneity in firing patterns between cells, the input-output curve was normalized to each cell's current threshold at its pre-treatment baseline. The current threshold was established from the current step at which the first action potential was generated. Input resistance was determined as $\Delta \mathrm{V} / \Delta \mathrm{l}$ using 10-50 pA hyperpolarizing current injections. First action potential elicited at rheobase was used to measure the action potential threshold, defined as the voltage at which the slope of the action potential (dv/dt) equals 10.

\section{Statistical analyses}

The experimenter (RS) was blind to behavioral treatment condition and throughout analysis of calcium imaging data. All data were analyzed using Graphpad Prism 8.0 and Excel. Raw data for $\mathrm{ED}_{50}$ calculations were converted to \% baseline responding (i.e. prior to CFA treatment) using the following formula: (Experimental Value - Post-CFA baseline)/(Pre-CFA baseline post-CFA baseline). $E D_{50}$ values were generated using nonlinear regression analysis in 
GraphPad 8.0. Behavioral data were analyzed via an ANOVA (two-way or one-way) followed by Tukey's post-hoc. In the case of only two groups, Bonferroni's post-hoc was used (Figure 4A). A one-way ANOVA followed by Tukey's post-hoc was used to compare the response ratio for calcium imaging groups. For all electrophysiology datasets, normality of residuals was tested using the Kolmogorov-Smirnov test, and parametric and non-parametric tests were used accordingly. Changes in current threshold and input resistance post-drug across conditions were analyzed using one-way ANOVA with Tukey's post-hoc. Change in voltage threshold postdrug across conditions was analyzed using Kruskal-Wallis test. Difference between pre- and post-drug current threshold and input resistance for each drug condition was evaluated using paired t-tests (parametric) and Wilcoxon matched-pairs signed rank test (non-parametric). Resting membrane potential across time was analyzed using one-way repeated measures ANOVA. For input-output data, mixed effects model with Tukey's post-hoc test was used for analysis. Detailed statistics including main effects and post-hoc comparisons are reported in the tables.

\section{Results:}

\section{CB-13 produces long-lasting analgesia mediated by peripheral $C_{1} B_{1}$ receptors in male and} female mice

CFA induced mechanical allodynia in both male and female mice, and this allodynia was dosedependently reduced by the peripherally restricted cannabinoid agonist CB-13, administered at approximately $20 \mathrm{~h}$ post-CFA injection. The $\mathrm{ED}_{50}$ for reduction of CFA-induced mechanical allodynia by CB-13 was $0.99 \mathrm{mg} / \mathrm{kg}(95 \% \mathrm{Cl} 0.49-2.00 \mathrm{mg} / \mathrm{kg})$ in male mice (Figure $1 \mathrm{~A}, \mathrm{~B})$ and $1.32 \mathrm{mg} / \mathrm{kg}(95 \% \mathrm{Cl} 0.46-3.23 \mathrm{mg} / \mathrm{kg})$ in female mice (Figure 1C,D) when measured $30 \mathrm{~min}$ post-drug injection. The $\mathrm{ED}_{50}$ values are comparable and the Cls overlap, suggesting efficacy of CB-13 did not differ between sexes. Male mice were used for all subsequent experiments. 
To determine the timecourse of CB-13 anti-allodynia, CB-13 (1, 3, or $10 \mathrm{mg} / \mathrm{kg}$ i.p.) or vehicle was administered after confirming CFA-induced hypersensitivity, as described above, and mechanical sensitivity was assessed for $24 \mathrm{~h}$ post-drug delivery. The reduction in CFA-induced mechanical allodynia by CB-13 was long-lasting (Fig. $1 E ; F_{18,150}=5.391, p<0.0001$, two-way ANOVA interaction effect). This effect appeared to be maximal at $30 \mathrm{~min}$ post-injection and lasted for at least $6 \mathrm{~h}$ for each dose (Figure 1E). The anti-allodynic effect of CB-13 (3 mg/kg i.p.) was completely abolished by the peripherally restricted $\mathrm{CB}_{1}$ antagonist AM6545 (10 mg/kg i.p., administered 30 min prior to CB-13). Administration of AM6545 did not alter mechanical thresholds on its own (Table 1; Figure 1F). These results demonstrate that the analgesic effects of $\mathrm{CB}-13$ are mediated exclusively by peripheral $\mathrm{CB}_{1}$ receptors.

\section{Repeated administration with $\mathrm{CB}-13$ results in antinociceptive tolerance and $\mathrm{CB}_{1}$ receptor-mediated dependence}

We next evaluated if CB-13 maintained efficacy over a repeated dosing schedule, or if tolerance would develop. CB-13 (1, 3, or 10 mg/kg i.p.) reduced CFA-induced mechanical allodynia $\left(F_{9,72}\right.$ $=7.792, \mathrm{p}<0.0001$, two-way ANOVA interaction effect) on days 1 and 3 of chronic daily dosing (Figure 2A; Table 2). By day 7 of repeated dosing, analgesic tolerance appeared to develop to all doses of CB-13.

The development of analgesic tolerance to $\mathrm{CB}_{1}$ receptor agonists is typically concurrent with $\mathrm{CB}_{1}$-mediated dependence [18,39]; therefore, we sought to evaluate if the animals receiving repeated doses of $\mathrm{CB}-13$ would also demonstrate $\mathrm{CB}_{1}$-mediated dependence. On day 9 of daily dosing, animals received a final injection of the assigned treatment condition, followed by administration of the $\mathrm{CB}_{1}$ antagonist rimonabant (10 mg/kg i.p.) $1 \mathrm{~h}$ later. In animals treated with CB-13, rimonabant administration elicited increased paw tremors $\left(F_{3,24}=5.971, p=0.0034\right.$, oneway ANOVA; Figure 2B). Treatment with $\mathrm{CB}-13$ also reduced rimonabant-evoked scratching behaviors $\left(F_{3,24}=10.78, p=0.0001\right.$, one-way ANOVA; Table 2; Figure $\left.2 \mathrm{C}\right)$, consistent with the 
development of $\mathrm{CB}_{1}$ receptor dependence following repeated dosing with $\mathrm{CB}-13$ even at doses that were previously reported[8] to be peripherally restricted and devoid of CNS side effects.

\section{CB-13 induces cardinal signs of central $C_{1}$ receptor activation independent of inflammatory status}

The development of anti-allodynic tolerance and rimonabant-evoked dependence phenotypes suggests potential engagement of central $\mathrm{CB}_{1}$ receptors over repeated dosing. To determine the timepoints in the repeated dosing regimen at which central $\mathrm{CB}_{1}$-mediated phenotypes emerge, we evaluated CB-13's effects on catalepsy, tail-flick antinociception and body temperature, which are phenotypes affected by central $\mathrm{CB}_{1}$ receptor activation $[20,26,47]$, on days 1,3 and 7 of daily CB-13 treatment in naïve (non-CFA-treated) mice. CB-13 increased the time spent immobile in the bar test of catalepsy behavior at the highest dose of $10 \mathrm{mg} / \mathrm{kg}$ i.p. on the first day of testing $\left(F_{14,112}=8.983, p<0.0001\right.$, two-way ANOVA interaction effect $)$, with the peak cataleptic effect occurring at $7.5 \mathrm{~h}$ post-injection (Figure $3 \mathrm{~A}$; Table 3). CB-13 also produced catalepsy on day $3\left(F_{14,112}=3.347, p=0.0002\right.$, two-way ANOVA interaction effect; Figure 3B) but did not induce catalepsy by day 7 of repeated dosing (Figure 3C). Importantly, catalepsy did not occur until $6 \mathrm{~h}$ post-injection of $10 \mathrm{mg} / \mathrm{kg} \mathrm{CB}-13$ (Figure 3A); thus, because the effects of CB-13 on CFA-induced allodynia were measured at $0.5 \mathrm{~h}$ post-drug administration (Figure 1; Figure 2A) and were noted to be maximal at that timepoint (Figure 1E), catalepsy was not a confounding variable in the anti-allodynia observed. CB-13 induced tail-flick antinociception $\left(F_{14,112}=5.921, p<0.0001\right.$, two-way ANOVA interaction effect $)$ at the highest dose tested (10 mg/kg i.p.) at $3 \mathrm{~h}$ post-injection (Figure 3D; Table 3). This effect was no longer evident on day 3 or 7 of sustained dosing (Figure 3E-F), consistent with the development of tolerance. CB-13 did not induce significant alterations in body temperature at any timepoint as measured by post-hoc analysis, although a trend to hypothermia is observed on day 1 at the highest dose tested $\left(F_{14,112}=2.255, p=0.0096\right.$, two-way ANOVA interaction effect; Figure 3G-I). 
Collectively, these data are consistent with the engagement of central $\mathrm{CB}_{1}$ receptors at a $\mathrm{CB}-13$ dose of $10 \mathrm{mg} / \mathrm{kg}$, even with acute dosing.

To evaluate if $\mathrm{CB}-13$-induced $\mathrm{CB}_{1}$ dependence was impacted by an inflammatory state, we tested whether chronic administration of CB-13 in naïve animals not administered CFA would also result in $\mathrm{CB}_{1}$ receptor dependence. As with the CFA-treated mice (Figure $2 \mathrm{~B}-\mathrm{C}$ ), rimonabant was administered on day 9 after a final dose of CB-13 (3 or $10 \mathrm{mg} / \mathrm{kg}$ i.p.) or vehicle in naïve mice. Chronic dosing with CB-13 again dose-dependently increased rimonabantinduced paw-tremors $\left(F_{2,15}=4.637, p=0.0271\right.$, one-way ANOVA; Figure 3J) and reduced rimonabant-elicited scratching behavior $\left(F_{2,15}=40.94, p<0.0001\right.$, one-way ANOVA; Figure 3K), indicative of $\mathrm{CB}_{1}$ receptor-dependence (Table 3). This result suggests that $\mathrm{CB}_{1}$ receptordependence induced by CB-13 is not reliant on the presence of an inflammatory state.

\section{CB-13 reduces CFA-induced thermal allodynia}

We next evaluated whether CB-13 can reduce thermal hyperalgesia following CFA administration, to test whether the analgesic effects of CB-13 would extend to other sensory modalities. CFA administration resulted in hypersensitivity to thermal stimulation $\left(F_{1,28}=109.1\right.$, $p<0.0001$, two-way ANOVA effect of time; Figure 4A). Using a dose that was maximally effective at reducing mechanical allodynia, CB-13 (3 mg/kg i.p.) reduced CFA-induced heat hypersensitivity $\left(F_{7,196}=2.563, p=0.0151\right.$, two-way ANOVA interaction effect; Table 4).

\section{CB-13 reduces PGE2-induced sensitization in cultured DRG neurons}

We next sought to evaluate if $\mathrm{CB}-13$ can reverse signs of peripheral sensitization induced by inflammatory mediators in isolated DRG neurons. We and others have shown that the inflammatory mediator PGE2 produces sensitization of the noxious heat transduction channel, TRPV1, and increases excitability in mouse DRG neurons $[17,35,66]$. We first assessed the ability of CB-13 to reduce PGE2-induced sensitization of TRPV1, as a plausible mechanism for 
reversal of inflammation-induced thermal hypersensitivity by CB-13 [34]. To this end, we employed calcium imaging of cultured mouse DRG neurons and confirmed the ability of PGE2 to sensitize responses to capsaicin application. Repeated application of capsaicin induced TRPV1 desensitization, as measured by a decrease in response to a second application of capsaicin (Figure 4B,E); when PGE2 was administered between capsaicin pulses, a sensitization effect was observed (Figure 4C,E; Table S4). When CB-13 (1 $\mu \mathrm{M})$ was applied 1 min prior to PGE2 and co-applied during the duration of PGE2 administration, it prevented the PGE2-induced increase in the capsaicin response ratio $\left(F_{(2,139)}=7.074, P=0.0012\right.$; Figure 4D-E; Table 4).

In addition to TRPV1 sensitization, PGE2 induces hyperexcitability of DRG neurons, which is another key peripheral process that contributes to nociceptive sensitization in the context of inflammation $[4,16,51,72,79,80]$. We used patch clamp electrophysiology to examine whether CB-13 can reduce PGE2-induced changes in DRG excitability. Bath application of $1 \mu \mathrm{M}$ PGE2 significantly increased action potential firing in response to depolarizing current injections (F $(1.000,10.00)=11.82, P=0.0063$, mixed effects model, PGE2 effect; Figure 5A, Table 5); PGE2treated cells had significantly more spike firing compared to vehicle-treated cells $\left(F_{(3,40)}=\right.$ 4.535, $P=0.0079$, mixed effects model, treatment effect; Figure 5E, Table 5). PGE2 additionally led to significant reduction in current threshold for action potential firing $\left(\mathrm{F}_{(3,40)}=7.534\right.$, $\mathrm{P}=0.0004$, one-way ANOVA; Figure 5F; Table 5). The effect of PGE2 on spike firing was blocked by co-application of $1 \mu \mathrm{M}$ CB-13 with PGE2 (Figure 5B,E; Table 5) but had no effect on PGE2-induced current threshold reduction. Application of CB-13 with PGE2 did not change the resting membrane potential, input resistance or voltage threshold for action potential of the recorded cell (Figure 5G-I; Table 5). To account for the potential effects of CB-13 or vehicle alone on action potential firing, we compared membrane excitability before and after treatment with either $1 \mu \mathrm{M}$ CB-13 alone or vehicle. Neither CB-13 nor vehicle alone had any effect on the 
input-output curve, current threshold, input resistance, resting membrane potential or voltage threshold (Figure 5C-I; Table 5). Treatment with PGE2, PGE2+CB-13, CB-13 alone or vehicle did not lead to any changes in action potential firing phenotypes in response to depolarizing current injections. Together, these results suggest that CB-13 can partially attenuate PGE2induced hyperexcitability in DRG neurons without affecting baseline membrane properties.

\section{Discussion}

In this study, we demonstrate that the peripherally selective $\mathrm{CB}_{1}$-preferring agonist $\mathrm{CB}-13$ produces equipotent efficacy in reducing inflammation-induced allodynia in male and female mice. With acute administration, the analgesic effect of $C B-13$ is peripherally mediated and is achieved at doses that do not produce behaviors indicative of central $\mathrm{CB}_{1}$ receptor engagement. Surprisingly, however, behavioral indicators of central $\mathrm{CB}_{1}$ receptor activation are present after acute dosing at doses higher than required for anti-allodynia, or when dosing periods are extended over several days. Finally, CB-13 reduces measures of TRPV1 sensitization and cellular hyperexcitability induced by the inflammatory mediator PGE2 in cultured DRG neurons, supporting the notion that activating $\mathrm{CB}_{1}$ in $\mathrm{DRG}$ neurons can produce an analgesic effect, and providing a potential mechanistic basis for our behavioral findings on anti-allodynic effects of CB-13.

Centrally penetrant cannabinoids, such as $\Delta^{9}$-THC, exhibit differential effectiveness between sexes at reducing allodynia in models of inflammatory and neuropathic pain $[10,12,13]$. In contrast, the peripherally restricted cannabinoid agonist PrNMI showed similar degrees of efficacy between sexes in a rat model of chemotherapy-induced peripheral neuropathy [52]. Our study complements these results, as CB-13 produced dose-dependent reductions of CFAinduced mechanical allodynia with a similar degree of efficacy between sexes in mice. Importantly, acute anti-allodynic efficacy of CB-13 was completely ablated when mice were 
pretreated with the peripherally restricted $C_{1}$ antagonist $A M 6545$, suggesting that $C B-13$ achieves anti-allodynia via peripheral $\mathrm{CB}_{1}$ receptors. This suggests that, although central mechanisms of cannabinoid-induced analgesia may differ, acute peripheral mechanisms may be independent of sex. It would be interesting to evaluate the potential sex difference of analgesic tolerance following repeated dosing with a peripherally selective $\mathrm{CB}_{1}$ agonist to better understand the interplay between sex and cannabinoid-mediated analgesia.

Compared to the wealth of behavioral studies linking $\mathrm{CB}_{1}$ receptor activation with antinociception and analgesia, relatively little is known about $\mathrm{CB}_{1}$ receptors and inflammationinduced changes in sensory neuron physiology. Prior studies have shown that $\mathrm{CB}_{1}$ receptor activation can block TRPV1 sensitization induced by NGF or bradykinin $[46,57,75]$. Consistent with this body of work, our calcium imaging results indicate that CB-13 reduces PGE2-induced TRPV1 sensitization in mouse DRG neurons (Figure 4). Interestingly, one recent abstract reported no effect of CB-13 on PGE2-induced TRPV1 sensitization in human sensory neurons [15]. The apparent discrepancy may be due to biological differences across species between mouse DRG and human and rat DRG, such as the lack of G protein-coupled inwardly rectifying potassium channels in mouse DRG neurons [56]. Regardless of this species difference, this work may be informative regarding the clinical utility of peripheral cannabinoid agonists in the context of different inflammatory states. Further work is needed to determine whether the effect of CB-13 generalizes to other inflammatory mediators, in both mouse and human sensory neurons. In our electrophysiology experiments, CB-13 partially attenuated PGE2-induced hyperexcitability in DRG neurons by reducing action potential firing (Figure 5). Although it has previously been reported that the endogenous cannabinoid anandamide (AEA) reduced action potential firing at baseline in rat DRG, CB-13 did not affect action potential firing in DRG neurons. These different results may be attributed to AEA metabolites interacting with voltagegated potassium channels [23], differences in culture conditions (e.g. 1-2 days employed here 
vs. 7 days in culture [23]) and species differences in DRG physiology. Our findings that CB-13 reduces PGE2-induced TRPV1 sensitization and neuronal hyperexcitability support a potential analgesic role for $\mathrm{CB}_{1}$ activation in the periphery, and provide a potential mechanistic basis for CB-13's anti-allodynic effects in the context of an inflammatory state.

The present study shows multiple phenotypic demonstrations of central penetrance by CB-13, including cannabinoid triad behaviors and $\mathrm{CB}_{1}$-mediated dependence. First, we found that acute dosing with CB-13 (10 mg/kg i.p.) produces catalepsy and tail-flick antinociception, behaviors indicative of central $\mathrm{CB}_{1}$ engagement. This was surprising, as the initial study of $\mathrm{CB}-13$ reported that administration of CB-13 at 0.2 or $2 \mathrm{mg} / \mathrm{kg}$ p.o. did not produce catalepsy in rats [22]. However, another group later reported a slight reduction in locomotor activity at CB-13 dose of 1 $\mathrm{mg} / \mathrm{kg}$ i.p. in C57BL/6N mice [8] and demonstrated that CB-13 produced hypothermia at 10 $\mathrm{mg} / \mathrm{kg}$ i.v. [61] and $5 \mathrm{mg} / \mathrm{kg}$ i.p.[60] in ABH mice. The relatively smaller hypothermic effect observed here (Figure 3G-I) could represent a difference in mouse strain (ABH vs. C57BL/6J)[58,61]. Interestingly, in our study tolerance developed differently between behaviors, as $10 \mathrm{mg} / \mathrm{kg}$ of CB-13 continued to produce catalepsy but not tail-flick antinociception on day 3 of dosing (Figure 3B,E). This may reflect a difference in dose sensitivity of the behaviors induced by central $\mathrm{CB}_{1}$ receptor engagement, as a recent report using the peripherally restricted agonist PrNMI demonstrated alterations in the open field assay with no effect on body temperature or hot plate response[83]. Indeed, it was previously demonstrated that the $\mathrm{ED}_{50}$ for producing catalepsy was lower than that of tail-flick antinociception and hypothermia for the centrally penetrant cannabinoid receptor agonists CP47,497 and $\Delta^{9-} \mathrm{THC}[27]$.

Our study is also the first to evaluate the occurrence of $\mathrm{CB}_{1}$ receptor dependence, a centrally mediated phenomenon $[19,36,64,70,73,74]$, following repeated dosing with a peripherally restricted cannabinoid receptor agonist. Strikingly, rimonabant challenge following treatment with CB-13 (3 and $10 \mathrm{mg} / \mathrm{kg}$ i.p.) once daily for 9 days resulted in an increase in paw tremors 
and relative decrease in rimonabant-evoked scratching behaviors, indicating $\mathrm{CB}_{1}$ receptor dependence was induced by chronic CB-13 treatment (Figure 2B-C; Figure 3J-K). Our finding was observed in both CFA-treated and CFA-naïve mice, suggesting the presence of an inflammatory state is not required for CB-13 to penetrate the CNS. This is important, as inflammatory status can alter $\mathrm{CB}_{1}$ receptor density and function[49] and blood brain barrier permeability in some cases [6].

Anti-allodynic tolerance has been demonstrated following repeated dosing of centrally penetrant $\mathrm{CB}_{1}$ agonists such as $\Delta^{9} \mathrm{THC}[19]$ and WIN55,212-2 [71], as well as monoacylglycerol lipase inhibitors [65,69]. Conversely, peripherally restricted cannabinoid ligands such as CB-13 and PrNMI have demonstrated no tolerance with repeated dosing in a rat models of neuropathic pain $[22,52]$, suggesting peripherally selective cannabinoid ligands may retain anti-allodynic efficacy without the development of tolerance. Once-daily dosing with CB-13 produced antiallodynic efficacy on days 1 and 3; surprisingly, tolerance developed by day 7 of dosing in all doses tested-including those that did not produce centrally mediated triad behaviors. This observation may reveal multiple possible interactions between CB-13 and peripheral and central nervous system components. First, these results may suggest that peripheral $\mathrm{CB}_{1}$ receptors may contribute to the development of anti-allodynic tolerance, in contrast to previous reports demonstrating tolerance only develops with central $\mathrm{CB}_{1}$ receptor agonists. Second, $\mathrm{CB}-13$ also exhibits affinity for $\mathrm{CB}_{2}$ receptors [22], and, although $\mathrm{CB}_{2}$ receptor agonists demonstrate antiallodynic efficacy that is devoid of tolerance $[19,29,62,63,76,82]$, it may also be possible that the interplay between $\mathrm{CB}_{1}$ and $\mathrm{CB}_{2}$ receptors contributes to the development of tolerance induced by CB-13. Finally, CNS exposure to CB-13 could increase following repeated dosing. As CB-13 is postulated to be excluded from the CNS via an ATP-binding cassette transport pump, accumulation of CB-13 may result in a saturation of this pump, leading to increased penetrability into the CNS [61]. It is unclear how CNS penetrance of CB-13 would lead to anti-allodynic 
tolerance, as the anti-allodynia caused by CB-13 was shown to be peripheral $\mathrm{CB}_{1}$-mediated acutely. One interpretation may be that functional $\mathrm{CB}_{1}$ desensitization in the central tissues renders peripheral $\mathrm{CB}_{1}$ activation to become no longer effective as witnessed with other centrally penetrant cannabinoid agonists $[18,19,40,50,54,71]$ and upregulation of 2 arachidonoylglycerol via monoacylglycerol lipase inhibition $[14,39,65]$. Further work is needed to better understand the mechanisms underlying anti-allodynic tolerance following repeated activation of $\mathrm{CB}_{1}$ receptors.

Overall, our findings show that acute treatment with a high analgesic dose of CB-13 engages central $\mathrm{CB}_{1}$ receptors. Although lower doses of $\mathrm{CB}-13$ yielded anti-allodynia while avoiding producing central $\mathrm{CB}_{1}$-mediated behaviors acutely, repeated dosing lead to central $\mathrm{CB}_{1}$ activation in mice. Clinical reports demonstrate that CB-13 produces side effects consistent with engagement of central $\mathrm{CB}_{1}$ receptors (e.g. sedation, psychoactivity) at higher doses $[25,38]$. Another peripherally restricted $\mathrm{CB}_{1}$-preferring agonist, AZD1940, also produced CNS-mediated effects of sedation and "high" feeling in healthy male volunteers that were greater at a higher dose $\left(800 \mu \mathrm{g}\right.$, administered orally)[38]. Our study demonstrates how central $\mathrm{CB}_{1}$ activation can arise from acute high doses or repeated low doses to produce unwanted side effects and thus has important implications for the use of existing peripherally restricted $\mathrm{CB}_{1}$-preferring ligands. Future efforts to target peripheral $\mathrm{CB}_{1}$ receptors for analgesia should therefore focus on improving the pharmacokinetic properties to limit CNS penetrance even at high doses or with long-term, repeated administration.

Together, our experiments suggest that $\mathrm{CB}_{1}$ receptor activation in peripheral sensory neurons may lead to analgesia in the context of inflammation by reducing TRPV1 sensitization and membrane hyperexcitability induced by inflammatory mediators. Our findings also show that whereas $\mathrm{CB}-13$ acutely produces peripheral $\mathrm{CB}_{1}$-mediated anti-allodynia, repeated dosing with CB-13 leads to anti-allodynic tolerance and central $\mathrm{CB}_{1}$-mediated dependence. These studies 
provide insight into the mechanistic basis and potential concerns of using currently available peripheral $\mathrm{CB}_{1}$ agonists for the treatment of chronic pain. It will be important for future studies to determine whether new molecules can be developed that maintain peripheral $\mathrm{CB}_{1}$ activity while reducing the potential for CNS exposure. A drug with these properties would enable clinical studies that can test the potential analgesic efficacy of full activation of peripheral $\mathrm{CB}_{1}$ receptors without dose-limiting side effects due to engagement of central $\mathrm{CB}_{1}$ receptors, and thus help improve the evidence base supporting (or not) the use of $\mathrm{CB}_{1}$ targeting medications for the treatment of pain[1].

\section{Funding and Disclosure}

This work was supported by grants from the National Institute of Neurological Disorders and

Stroke (R01 NS042595; RWG), National Institute on Drug Abuse (F32 DA051160; RAS),

National Institute of General Medical Sciences (T32 GM108539; VEB), Washington University in

St Louis (Dr. Seymour and Rose T. Brown Professorship in Anesthesiology, RWG; Lucille P. Markey Pathway in Human Pathobiology, JY). The authors declare no competing interests.

\section{Acknowledgments}

We thank the entire Gereau lab for helpful comments and critiques. 


\section{References}

[1] International Association for the Study of Pain presidential task force on cannabis and cannabinoid analgesia position statement. Pain 2021.

[2] Abraham AD, Leung EJY, Wong BA, Rivera ZMG, Kruse LC, Clark JJ, Land BB. Orally consumed cannabinoids provide long-lasting relief of allodynia in a mouse model of chronic neuropathic pain. Neuropsychopharmacology 2019.

[3] Agarwal N, Pacher P, Tegeder I, Amaya F, Constantin CE, Brenner GJ, Rubino T, Michalski CW, Marsicano G, Monory K, Mackie K, Marian C, Batkai S, Parolaro D, Fischer MJ, Reeh P, Kunos G, Kress M, Lutz B, Woolf CJ, Kuner R. Cannabinoids mediate analgesia largely via peripheral type 1 cannabinoid receptors in nociceptors. Nat Neurosci 2007;10(7):870-879.

[4] Asiedu MN, Tillu DV, Melemedjian OK, Shy A, Sanoja R, Bodell B, Ghosh S, Porreca F, Price TJ. Spinal protein kinase $M$ zeta underlies the maintenance mechanism of persistent nociceptive sensitization. J Neurosci 2011;31(18):6646-6653.

[5] Bartsch VB, Niehaus JK, Taylor-Blake B, Zylka MJ. Enhanced histamine-induced itch in diacylglycerol kinase iota knockout mice. PLoS One 2019;14(6):e0217819.

[6] Brooks TA, Hawkins BT, Huber JD, Egleton RD, Davis TP. Chronic inflammatory pain leads to increased blood-brain barrier permeability and tight junction protein alterations. Am J Physiol Heart Circ Physiol 2005;289(2):H738-743.

[7] Clapper JR, Moreno-Sanz G, Russo R, Guijarro A, Vacondio F, Duranti A, Tontini A, Sanchini S, Sciolino NR, Spradley JM, Hohmann AG, Calignano A, Mor M, Tarzia G, Piomelli D. Anandamide suppresses pain initiation through a peripheral endocannabinoid mechanism. Nat Neurosci 2010;13(10):1265-1270.

[8] Cluny NL, Keenan CM, Duncan M, Fox A, Lutz B, Sharkey KA. Naphthalen-1-yl-(4pentyloxynaphthalen-1-yl)methanone (SAB378), a peripherally restricted cannabinoid CB1/CB2 receptor agonist, inhibits gastrointestinal motility but has no effect on experimental colitis in mice. J Pharmacol Exp Ther 2010;334(3):973-980.

[9] Cluny NL, Vemuri VK, Chambers AP, Limebeer CL, Bedard H, Wood JT, Lutz B, Zimmer A, Parker LA, Makriyannis A, Sharkey KA. A novel peripherally restricted cannabinoid receptor antagonist, AM6545, reduces food intake and body weight, but does not cause malaise, in rodents. Br J Pharmacol 2010;161(3):629-642.

[10] Cooper ZD, Craft RM. Sex-Dependent Effects of Cannabis and Cannabinoids: A Translational Perspective. Neuropsychopharmacology 2018;43(1):34-51.

[11] Costa B, Colleoni M, Conti S, Trovato AE, Bianchi M, Sotgiu ML, Giagnoni G. Repeated treatment with the synthetic cannabinoid WIN 55,212-2 reduces both hyperalgesia and production of pronociceptive mediators in a rat model of neuropathic pain. $\mathrm{Br} \mathrm{J}$ Pharmacol 2004;141(1):4-8.

[12] Craft RM, Marusich JA, Wiley JL. Sex differences in cannabinoid pharmacology: a reflection of differences in the endocannabinoid system? Life Sci 2013;92(8-9):476-481.

[13] Craft RM, Wakley AA, Tsutsui KT, Laggart JD. Sex differences in cannabinoid 1 vs. cannabinoid 2 receptor-selective antagonism of antinociception produced by delta9tetrahydrocannabinol and CP55,940 in the rat. J Pharmacol Exp Ther 2012;340(3):787800.

[14] Curry ZA, Wilkerson JL, Bagdas D, Kyte SL, Patel N, Donvito G, Mustafa MA, Poklis JL, Niphakis MJ, Hsu KL, Cravatt BF, Gewirtz DA, Damaj MI, Lichtman AH. Monoacylglycerol Lipase Inhibitors Reverse Paclitaxel-Induced Nociceptive Behavior and Proinflammatory Markers in a Mouse Model of Chemotherapy-Induced Neuropathy. J Pharmacol Exp Ther 2018;366(1):169-183. 
[15] Davidson S, Ford, Z., Chen, S. (255) Effects of Cannabinoids on Responses of Human Dorsal Root Ganglia Neuron. American Pain Society Vol. 20. Milwaukee, WI: The Journal of Pain, 2019.

[16] Davidson S, Golden JP, Copits BA, Ray PR, Vogt SK, Valtcheva MV, Schmidt RE, Ghetti A, Price TJ, Gereau RWt. Group II mGluRs suppress hyperexcitability in mouse and human nociceptors. Pain 2016;157(9):2081-2088.

[17] Davidson S, Golden JP, Copits BA, Ray PR, Vogt SK, Valtcheva MV, Schmidt RE, Ghetti A, Price TJ, Gereau RWt. Group II mGluRs suppress hyperexcitability in mouse and human nociceptors. Pain 2016;157(9):2081-2088.

[18] Deng L, Cornett BL, Mackie K, Hohmann AG. CB1 Knockout Mice Unveil Sustained CB2Mediated Antiallodynic Effects of the Mixed CB1/CB2 Agonist CP55,940 in a Mouse Model of Paclitaxel-Induced Neuropathic Pain. Mol Pharmacol 2015;88(1):64-74.

[19] Deng L, Guindon J, Cornett BL, Makriyannis A, Mackie K, Hohmann AG. Chronic cannabinoid receptor 2 activation reverses paclitaxel neuropathy without tolerance or cannabinoid receptor 1-dependent withdrawal. Biol Psychiatry 2015;77(5):475-487.

[20] Di Marzo V, Griffin G, De Petrocellis L, Brandi I, Bisogno T, Williams W, Grier MC, Kulasegram S, Mahadevan A, Razdan RK, Martin BR. A structure/activity relationship study on arvanil, an endocannabinoid and vanilloid hybrid. J Pharmacol Exp Ther 2002;300(3):984-991.

[21] Dyson A, Peacock M, Chen A, Courade JP, Yaqoob M, Groarke A, Brain C, Loong Y, Fox A. Antihyperalgesic properties of the cannabinoid CT-3 in chronic neuropathic and inflammatory pain states in the rat. Pain 2005;116(1-2):129-137.

[22] Dziadulewicz EK, Bevan SJ, Brain CT, Coote PR, Culshaw AJ, Davis AJ, Edwards LJ, Fisher AJ, Fox AJ, Gentry C, Groarke A, Hart TW, Huber W, James IF, Kesingland A, La Vecchia L, Loong Y, Lyothier I, McNair K, O'Farrell C, Peacock M, Portmann R, Schopfer U, Yaqoob M, Zadrobilek J. Naphthalen-1-yl-(4-pentyloxynaphthalen-1yl)methanone: a potent, orally bioavailable human CB1/CB2 dual agonist with antihyperalgesic properties and restricted central nervous system penetration. J Med Chem 2007;50(16):3851-3856.

[23] Evans RM, Wease KN, MacDonald CJ, Khairy HA, Ross RA, Scott RH. Modulation of sensory neuron potassium conductances by anandamide indicates roles for metabolites. Br J Pharmacol 2008;154(2):480-492.

[24] Friard O, Gamba M. BORIS: a free, versatile open-source event-logging software for video/audio coding and live observations. Methods in Ecology and Evolution 2016;7(11):1325-1330.

[25] Gardin A, Kucher K, Kiese B, Appel-Dingemanse S. Cannabinoid receptor agonist 13, a novel cannabinoid agonist: first in human pharmacokinetics and safety. Drug Metab Dispos 2009;37(4):827-833.

[26] Grim TW, Morales AJ, Gonek MM, Wiley JL, Thomas BF, Endres GW, Sim-Selley LJ, Selley DE, Negus SS, Lichtman AH. Stratification of Cannabinoid 1 Receptor (CB1R) Agonist Efficacy: Manipulation of CB1R Density through Use of Transgenic Mice Reveals Congruence between In Vivo and In Vitro Assays. J Pharmacol Exp Ther 2016;359(2):329-339.

[27] Grim TW, Samano KL, Ignatowska-Jankowska B, Tao Q, Sim-Selly LJ, Selley DE, Wise LE, Poklis A, Lichtman AH. Pharmacological characterization of repeated administration of the first generation abused synthetic cannabinoid CP47,497. J Basic Clin Physiol Pharmacol 2016;27(3):217-228.

[28] Guindon J, Lai Y, Takacs SM, Bradshaw HB, Hohmann AG. Alterations in endocannabinoid tone following chemotherapy-induced peripheral neuropathy: effects of endocannabinoid deactivation inhibitors targeting fatty-acid amide hydrolase and monoacylglycerol lipase 
in comparison to reference analgesics following cisplatin treatment. Pharmacol Res 2013;67(1):94-109.

[29] Gutierrez T, Farthing JN, Zvonok AM, Makriyannis A, Hohmann AG. Activation of peripheral cannabinoid $\mathrm{CB} 1$ and $\mathrm{CB} 2$ receptors suppresses the maintenance of inflammatory nociception: a comparative analysis. Br J Pharmacol 2007;150(2):153-163.

[30] Herkenham M, Lynn AB, Little MD, Johnson MR, Melvin LS, de Costa BR, Rice KC. Cannabinoid receptor localization in brain. Proc Natl Acad Sci U S A 1990;87(5):19321936.

[31] Hill KP. Medical Marijuana for Treatment of Chronic Pain and Other Medical and Psychiatric Problems: A Clinical Review. JAMA 2015;313(24):2474-2483.

[32] Hohmann AG, Briley EM, Herkenham M. Pre- and postsynaptic distribution of cannabinoid and mu opioid receptors in rat spinal cord. Brain Res 1999;822(1-2):17-25.

[33] Hohmann AG, Herkenham M. Localization of central cannabinoid CB1 receptor messenger RNA in neuronal subpopulations of rat dorsal root ganglia: a double-label in situ hybridization study. Neuroscience 1999;90(3):923-931.

[34] Honore P, Wismer CT, Mikusa J, Zhu CZ, Zhong C, Gauvin DM, Gomtsyan A, El Kouhen R, Lee CH, Marsh K, Sullivan JP, Faltynek CR, Jarvis MF. A-425619 [1-isoquinolin-5-yl3-(4-trifluoromethyl-benzyl)-urea], a novel transient receptor potential type $\mathrm{V} 1$ receptor antagonist, relieves pathophysiological pain associated with inflammation and tissue injury in rats. J Pharmacol Exp Ther 2005;314(1):410-421.

[35] Hu HJ, Alter BJ, Carrasquillo Y, Qiu CS, Gereau RWt. Metabotropic glutamate receptor 5 modulates nociceptive plasticity via extracellular signal-regulated kinase-Kv4.2 signaling in spinal cord dorsal horn neurons. J Neurosci 2007;27(48):13181-13191.

[36] Huang P, Liu-Chen LY, Unterwald EM, Cowan A. Hyperlocomotion and paw tremors are two highly quantifiable signs of SR141716-precipitated withdrawal from delta9tetrahydrocannabinol in C57BL/6 mice. Neurosci Lett 2009;465(1):66-70.

[37] Jamison RN, Mao J. Opioid Analgesics. Mayo Clinic proceedings 2015;90(7):957-968.

[38] Kalliomaki J, Annas P, Huizar K, Clarke C, Zettergren A, Karlsten R, Segerdahl M. Evaluation of the analgesic efficacy and psychoactive effects of AZD1940, a novel peripherally acting cannabinoid agonist, in human capsaicin-induced pain and hyperalgesia. Clin Exp Pharmacol Physiol 2013;40(3):212-218.

[39] Kinsey SG, Wise LE, Ramesh D, Abdullah R, Selley DE, Cravatt BF, Lichtman AH. Repeated low-dose administration of the monoacylglycerol lipase inhibitor JZL184 retains cannabinoid receptor type 1-mediated antinociceptive and gastroprotective effects. J Pharmacol Exp Ther 2013;345(3):492-501.

[40] LaFleur RA, Wilson RP, Morgan DJ, Henderson-Redmond AN. Sex differences in antinociceptive response to Delta-9-tetrahydrocannabinol and CP 55,940 in the mouse formalin test. Neuroreport 2018;29(6):447-452.

[41] Li AL, Lin X, Dhopeshwarkar AS, Thomaz AC, Carey LM, Liu Y, Nikas SP, Makriyannis A, Mackie K, Hohmann AG. Cannabinoid CB2 Agonist AM1710 Differentially Suppresses Distinct Pathological Pain States and Attenuates Morphine Tolerance and Withdrawal. Mol Pharmacol 2019;95(2):155-168.

[42] Lichtman AH, Fisher J, Martin BR. Precipitated cannabinoid withdrawal is reversed by Delta(9)-tetrahydrocannabinol or clonidine. Pharmacol Biochem Behav 2001;69(12):181-188.

[43] Lichtman AH, Sheikh SM, Loh HH, Martin BR. Opioid and cannabinoid modulation of precipitated withdrawal in delta(9)-tetrahydrocannabinol and morphine-dependent mice. J Pharmacol Exp Ther 2001;298(3):1007-1014.

[44] Little PJ, Compton DR, Johnson MR, Melvin LS, Martin BR. Pharmacology and stereoselectivity of structurally novel cannabinoids in mice. J Pharmacol Exp Ther 1988;247(3):1046-1051. 
[45] Madasu MK, Thang LV, Chilukuri P, Palanisamy S, Arackal JS, Sheahan TD, Foshage AM, Houghten RA, McLaughlin JP, McCall JG, Al-Hasani R. Peripheral kappa opioid receptor activation drives cold hypersensitivity in mice. bioRxiv 2021:2020.2010.2004.325118.

[46] McDowell TS, Wang ZY, Singh R, Bjorling D. CB1 cannabinoid receptor agonist prevents NGF-induced sensitization of TRPV1 in sensory neurons. Neurosci Lett 2013;551:34-38.

[47] Metna-Laurent M, Mondesir M, Grel A, Vallee M, Piazza PV. Cannabinoid-Induced Tetrad in Mice. Curr Protoc Neurosci 2017;80:9 59 51-59 5910.

[48] Millan MJ, Czlonkowski A, Morris B, Stein C, Arendt R, Huber A, Hollt V, Herz A. Inflammation of the hind limb as a model of unilateral, localized pain: influence on multiple opioid systems in the spinal cord of the rat. Pain 1988;35(3):299-312.

[49] Miller LK, Devi LA. The highs and lows of cannabinoid receptor expression in disease: mechanisms and their therapeutic implications. Pharmacol Rev 2011;63(3):461-470.

[50] Morgan DJ, Davis BJ, Kearn CS, Marcus D, Cook AJ, Wager-Miller J, Straiker A, Myoga $\mathrm{MH}$, Karduck J, Leishman E, Sim-Selley LJ, Czyzyk TA, Bradshaw HB, Selley DE, Mackie K. Mutation of putative GRK phosphorylation sites in the cannabinoid receptor 1 (CB1R) confers resistance to cannabinoid tolerance and hypersensitivity to cannabinoids in mice. J Neurosci 2014;34(15):5152-5163.

[51] Moriyama T, Higashi T, Togashi K, lida T, Segi E, Sugimoto Y, Tominaga T, Narumiya S, Tominaga M. Sensitization of TRPV1 by EP1 and IP reveals peripheral nociceptive mechanism of prostaglandins. Mol Pain 2005;1:3.

[52] Mulpuri Y, Marty VN, Munier JJ, Mackie K, Schmidt BL, Seltzman HH, Spigelman I. Synthetic peripherally-restricted cannabinoid suppresses chemotherapy-induced peripheral neuropathy pain symptoms by CB1 receptor activation. Neuropharmacology 2018;139:85-97.

[53] Nahin RL. Estimates of Pain Prevalence and Severity in Adults: United States, 2012. The journal of pain : official journal of the American Pain Society 2015.

[54] Nealon CM, Henderson-Redmond AN, Hale DE, Morgan DJ. Tolerance to WIN55,212-2 is delayed in desensitization-resistant S426A/S430A mice. Neuropharmacology 2019;148:151-159.

[55] Nielsen S, Sabioni P, Trigo JM, Ware MA, Betz-Stablein BD, Murnion B, Lintzeris N, Khor KE, Farrell M, Smith A, Le Foll B. Opioid-Sparing Effect of Cannabinoids: A Systematic Review and Meta-Analysis. Neuropsychopharmacology 2017;42(9):1752-1765.

[56] Nockemann D, Rouault M, Labuz D, Hublitz P, McKnelly K, Reis FC, Stein C, Heppenstall $\mathrm{PA}$. The $\mathrm{K}(+)$ channel GIRK2 is both necessary and sufficient for peripheral opioidmediated analgesia. EMBO Mol Med 2013;5(8):1263-1277.

[57] Oshita K, Inoue A, Tang HB, Nakata Y, Kawamoto M, Yuge O. CB(1) cannabinoid receptor stimulation modulates transient receptor potential vanilloid receptor 1 activities in calcium influx and substance P Release in cultured rat dorsal root ganglion cells. J Pharmacol Sci 2005;97(3):377-385.

[58] Parks C, Jones, B. , Moore, B., and Mulligan, M. Sex and Strain Variation in Initial Sensitivity and Rapid Tolerance to $\Delta 9$-Tetrahydrocannabinol. Cannabis and Cannabinoid Research 2020;0(0):null.

[59] Pertwee RG, Howlett AC, Abood ME, Alexander SP, Di Marzo V, Elphick MR, Greasley PJ, Hansen HS, Kunos G, Mackie K, Mechoulam R, Ross RA. International Union of Basic and Clinical Pharmacology. LXXIX. Cannabinoid receptors and their ligands: beyond CB(1) and CB(2). Pharmacol Rev 2010;62(4):588-631.

[60] Pryce G, Baker D. Antidote to cannabinoid intoxication: the CB1 receptor inverse agonist, AM251, reverses hypothermic effects of the CB1 receptor agonist, CB-13, in mice. Br J Pharmacol 2017;174(21):3790-3794.

[61] Pryce G, Visintin C, Ramagopalan SV, Al-Izki S, De Faveri LE, Nuamah RA, Mein CA, Montpetit A, Hardcastle AJ, Kooij G, de Vries HE, Amor S, Thomas SA, Ledent C, 
Marsicano G, Lutz B, Thompson AJ, Selwood DL, Giovannoni G, Baker D. Control of spasticity in a multiple sclerosis model using central nervous system-excluded CB1 cannabinoid receptor agonists. FASEB J 2014;28(1):117-130.

[62] Rahn EJ, Hohmann AG. Cannabinoids as pharmacotherapies for neuropathic pain: from the bench to the bedside. Neurotherapeutics : the journal of the American Society for Experimental NeuroTherapeutics 2009;6(4):713-737.

[63] Rahn EJ, Thakur GA, Wood JA, Zvonok AM, Makriyannis A, Hohmann AG. Pharmacological characterization of AM1710, a putative cannabinoid CB2 agonist from the cannabilactone class: antinociception without central nervous system side-effects. Pharmacol Biochem Behav 2011;98(4):493-502.

[64] Ramesh D, Schlosburg JE, Wiebelhaus JM, Lichtman AH. Marijuana dependence: not just smoke and mirrors. ILAR J 2011;52(3):295-308.

[65] Schlosburg JE, Blankman JL, Long JZ, Nomura DK, Pan B, Kinsey SG, Nguyen PT, Ramesh D, Booker L, Burston JJ, Thomas EA, Selley DE, Sim-Selley LJ, Liu QS, Lichtman AH, Cravatt BF. Chronic monoacylglycerol lipase blockade causes functional antagonism of the endocannabinoid system. Nat Neurosci 2010;13(9):1113-1119.

[66] Sheahan TD, Valtcheva MV, Mcllvried LA, Pullen MY, Baranger DAA, Gereau RWt. Metabotropic Glutamate Receptor 2/3 (mGluR2/3) Activation Suppresses TRPV1 Sensitization in Mouse, But Not Human, Sensory Neurons. eNeuro 2018;5(2).

[67] Sim LJ, Hampson RE, Deadwyler SA, Childers SR. Effects of chronic treatment with delta9tetrahydrocannabinol on cannabinoid-stimulated [35S]GTPgammaS autoradiography in rat brain. J Neurosci 1996;16(24):8057-8066.

[68] Slivicki RA, Saberi SA, lyer V, Vemuri K, Makriyannis A, Hohmann AG. Brain permeant and impermeant inhibitors of fatty-acid amide hydrolase synergize with the opioid analgesic morphine to suppress chemotherapy-induced neuropathic nociception without enhancing effects of morphine on gastrointestinal transit. J Pharmacol Exp Ther 2018.

[69] Slivicki RA, Xu Z, Kulkarni PM, Pertwee RG, Mackie K, Thakur GA, Hohmann AG. Positive Allosteric Modulation of Cannabinoid Receptor Type 1 Suppresses Pathological Pain Without Producing Tolerance or Dependence. Biol Psychiatry 2017.

[70] Slivicki RA, Xu Z, Kulkarni PM, Pertwee RG, Mackie K, Thakur GA, Hohmann AG. Positive Allosteric Modulation of Cannabinoid Receptor Type 1 Suppresses Pathological Pain Without Producing Tolerance or Dependence. Biol Psychiatry 2018;84(10):722-733.

[71] Slivicki RA, Xu Z, Mali SS, Hohmann AG. Brain permeant and impermeant inhibitors of fatty-acid amide hydrolase suppress the development and maintenance of paclitaxelinduced neuropathic pain without producing tolerance or physical dependence in vivo and synergize with paclitaxel to reduce tumor cell line viability in vitro. Pharmacol Res 2019;142:267-282.

[72] Tavares-Ferreira D, Ray PR, Sankaranarayanan I, Mejia GL, Wangzhou A, Shiers S, Uttarkar R, Megat S, Barragan-Iglesias P, Dussor G, Akopian AN, Price TJ. Sex Differences in Nociceptor Translatomes Contribute to Divergent Prostaglandin Signaling in Male and Female Mice. Biol Psychiatry 2020.

[73] Trexler KR, Eckard ML, Kinsey SG. CB1 positive allosteric modulation attenuates Delta(9)THC withdrawal and NSAID-induced gastric inflammation. Pharmacol Biochem Behav 2019;177:27-33.

[74] Trexler KR, Nass SR, Crowe MS, Gross JD, Jones MS, McKitrick AW, Siderovski DP, Kinsey SG. Novel behavioral assays of spontaneous and precipitated THC withdrawal in mice. Drug Alcohol Depend 2018;191:14-24.

[75] Wang ZY, McDowell T, Wang P, Alvarez R, Gomez T, Bjorling DE. Activation of CB1 inhibits NGF-induced sensitization of TRPV1 in adult mouse afferent neurons. Neuroscience 2014;277:679-689. 
[76] Wilkerson JL, Gentry KR, Dengler EC, Wallace JA, Kerwin AA, Kuhn MN, Zvonok AM, Thakur GA, Makriyannis A, Milligan ED. Immunofluorescent spectral analysis reveals the intrathecal cannabinoid agonist, AM1241, produces spinal anti-inflammatory cytokine responses in neuropathic rats exhibiting relief from allodynia. Brain Behav 2012;2(2):155-177.

[77] Woodhams SG, Chapman V, Finn DP, Hohmann AG, Neugebauer V. The cannabinoid system and pain. Neuropharmacology 2017;124:105-120.

[78] Yamamoto T, Mulpuri Y, Izraylev M, Li Q, Simonian M, Kramme C, Schmidt BL, Seltzman $\mathrm{HH}$, Spigelman I. Selective targeting of peripheral cannabinoid receptors prevents behavioral symptoms and sensitization of trigeminal neurons in mouse models of migraine and medication overuse headache. Pain 2021.

[79] Yang D, Gereau RWt. Peripheral group II metabotropic glutamate receptors (mGluR2/3) regulate prostaglandin E2-mediated sensitization of capsaicin responses and thermal nociception. J Neurosci 2002;22(15):6388-6393.

[80] Yang D, Gereau RWt. Peripheral group II metabotropic glutamate receptors mediate endogenous anti-allodynia in inflammation. Pain 2003;106(3):411-417.

[81] Yu XH, Cao CQ, Martino G, Puma C, Morinville A, St-Onge S, Lessard E, Perkins MN, Laird JMA. A peripherally restricted cannabinoid receptor agonist produces robust antinociceptive effects in rodent models of inflammatory and neuropathic pain. Pain 2010;151(2):337-344.

[82] Yuill MB, Hale DE, Guindon J, Morgan DJ. Anti-nociceptive interactions between opioids and a cannabinoid receptor 2 agonist in inflammatory pain. Mol Pain 2017;13:1744806917728227.

[83] Zhang H, Lund DM, Ciccone HA, Staatz WD, Ibrahim MM, Largent-Milnes TM, Seltzman $\mathrm{HH}$, Spigelman I, Vanderah TW. Peripherally restricted cannabinoid 1 receptor agonist as a novel analgesic in cancer-induced bone pain. Pain 2018;159(9):1814-1823. 


\section{Figure 1}
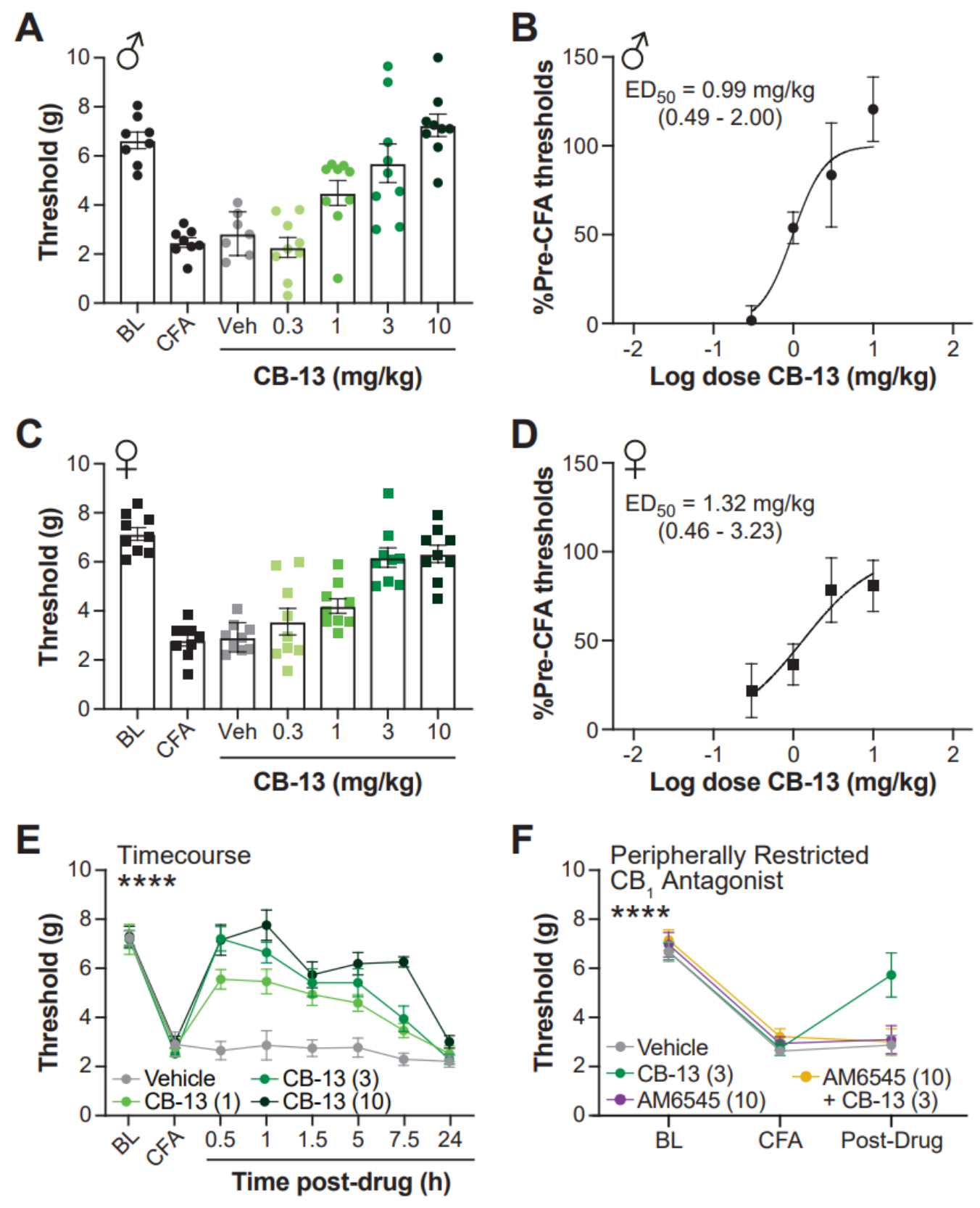

Figure 1: Administration of CB-13 produces a long-lasting dose-dependent reduction in CFA-induced mechanical allodynia that is dependent on $\mathrm{CB}_{1}$ receptor activation in the periphery. CB-13 $(0.3,1,3,10 \mathrm{mg} / \mathrm{kg}$ i.p.) reduced CFA-induced mechanical allodynia in a dose-dependent manner that was equipotent in both males $(A, B)$ and females (C,D). CB-13's anti-allodynic effects are long-lasting $(E)(B L=$ baseline, CFA $=24 \mathrm{hr}$ post-CFA, but 
pretreatment with vehicle or $\mathrm{CB}-13)$. Pre-treatment with the peripherally restricted $\mathrm{CB}_{1}$ receptor antagonist AM6545 (10 mg/kg i.p.) prevents the analgesic effect of CB-13 (3 mg/kg i.p.), but has no effect on its own (F). ED 50 values (in $\mathrm{mg} / \mathrm{kg}$ ) displayed with $95 \%$ confidence intervals on graphs in (B) and (D). ${ }^{* * *} \mathrm{P}<0.00012 \times 2$ ANOVA interaction effect all timepoints post-CFA. (E). ${ }^{* * *} \mathrm{P}<0.0001$ One-way ANOVA post-drug timepoint $(\mathrm{F})$. Post-tests and other statistics are reported in Table 1. Data are expressed as mean \pm SEM. $N=7-9$ per group. 


\section{Figure 2}
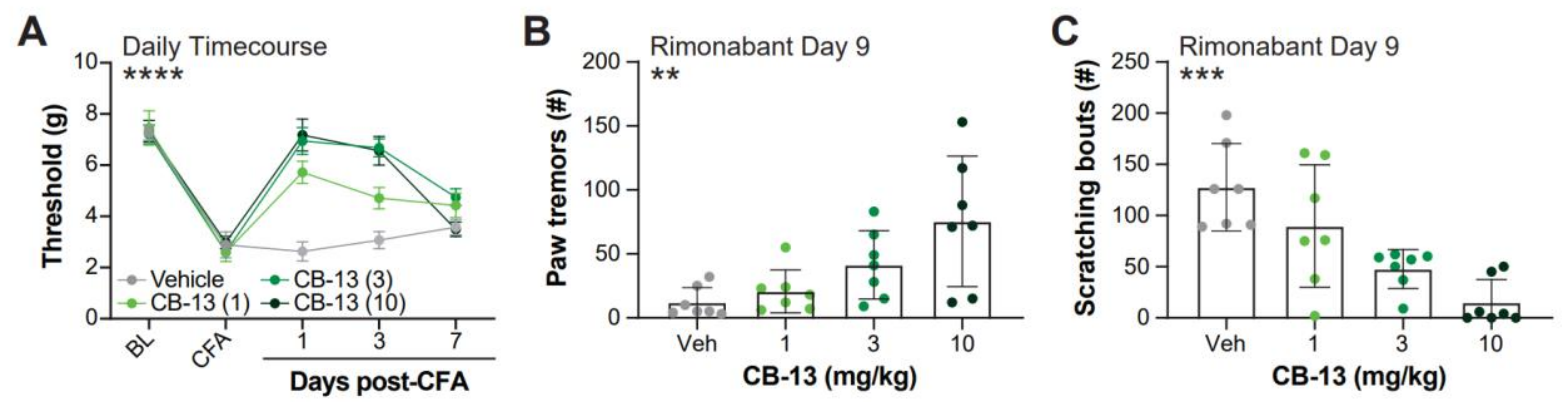

Figure 2. Sustained administration of $C B-13$ produces analgesic tolerance and $C_{1}$ receptor dependence in CFA-treated mice. Following baseline (BL) assessment and the induction of CFA-induced inflammation, animals were randomized to receive 1,3 or $10 \mathrm{mg} / \mathrm{kg}$ i.p. of $\mathrm{CB}-13$ or vehicle and evaluated for mechanical responsivity 30 min following treatment administration on days 1,3 and 7 . All doses were effective on days 1 and 3 , but by day 7 tolerance developed to the anti-allodynic effect of CB-13 (A). On day 9 the $\mathrm{CB}_{1}$ antagonist rimonabant (10 mg/kg i.p.) was administered $1 \mathrm{~h}$ following the final injection of $\mathrm{CB}-13$ or vehicle. Chronic treatment with 3 or $10 \mathrm{mg} / \mathrm{kg}$ increased rimonabant-elicited paw tremors (B) and decreased rimonabant-elicited scratching behaviors $(C)$, consistent with the development of $\mathrm{CB}_{1}$ receptor dependence. ${ }^{* * *} \mathrm{P}<0.00012 \times 2$ ANOVA interaction effect in $(\mathrm{A}) .{ }^{* *} \mathrm{P}<0.01,{ }^{* * *} \mathrm{P}<$ 0.001 One-way ANOVA effect of treatment in (B) and (C). Post-tests and other statistics are reported in Table S2. Data are expressed as mean \pm SEM. $N=7-9$ per group. 


\section{Figure 3}
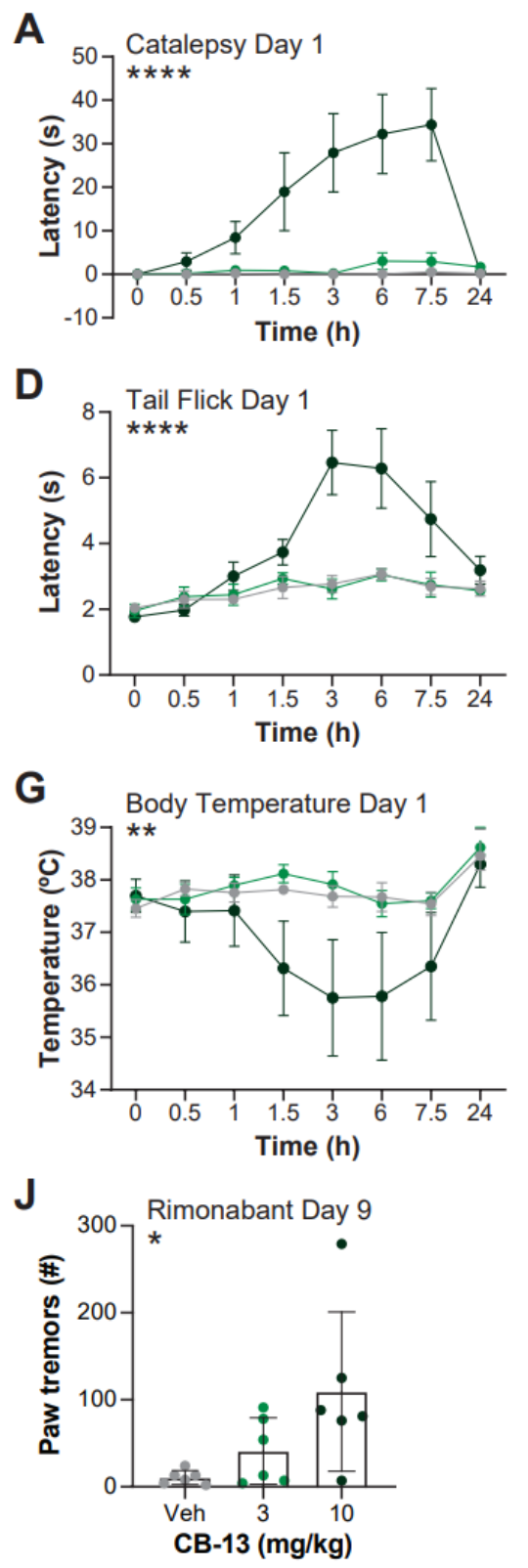

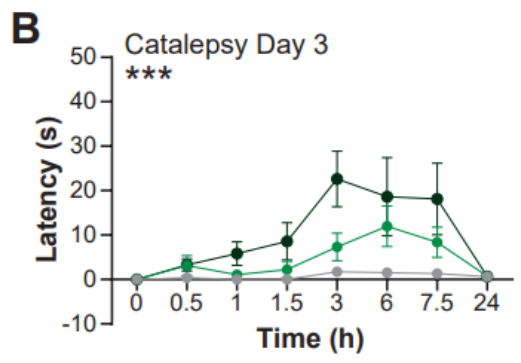

E
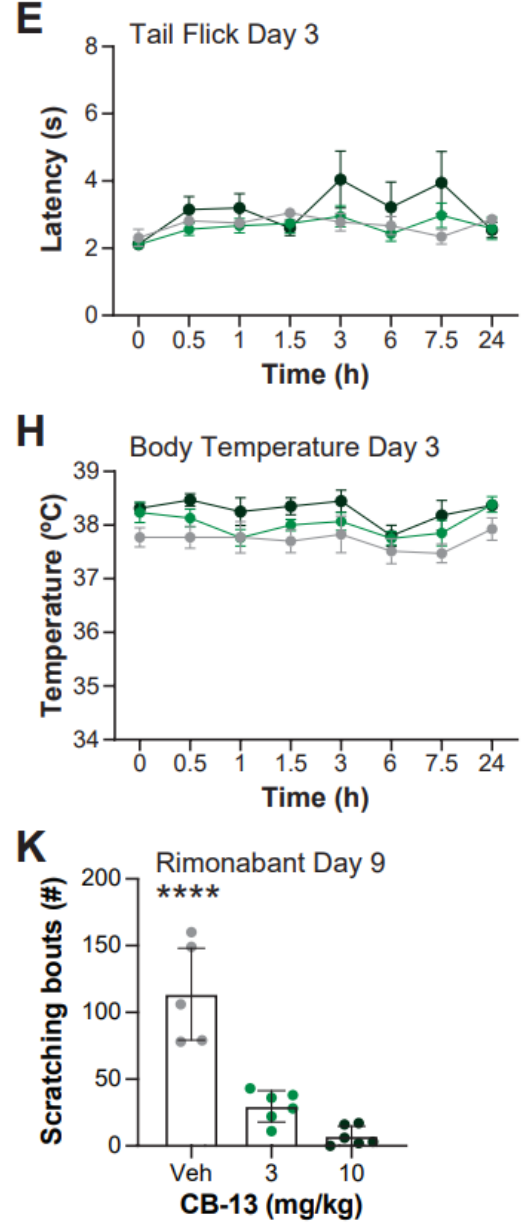
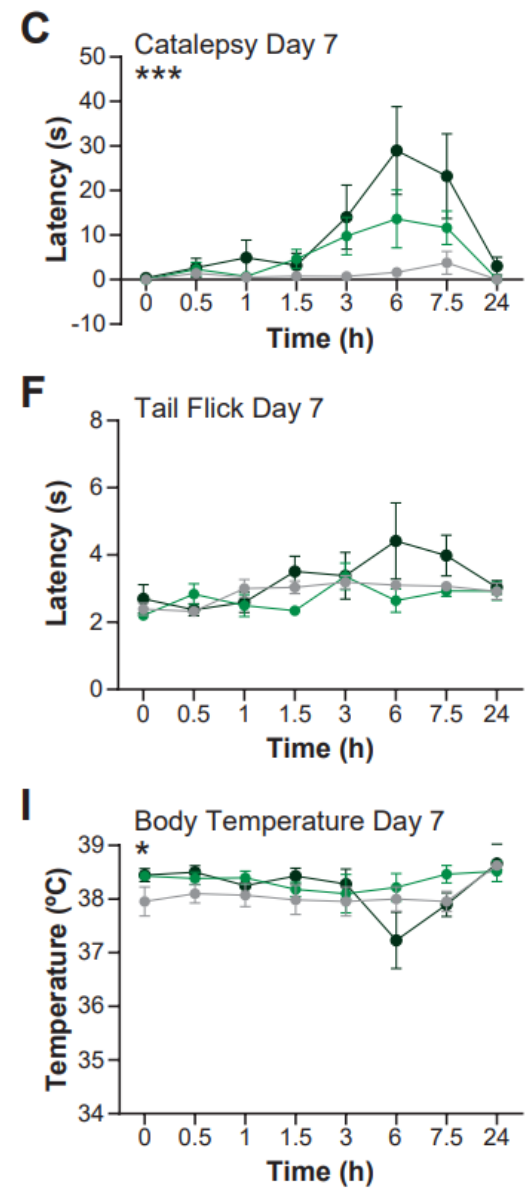

Legend for all panels:

$\rightarrow$ Vehicle

$\rightarrow$ CB-13 (3)

$\rightarrow-\mathrm{CB}-13(10)$

Figure 3. $C B-13$ produces cardinal signs of $C N S C_{1}$ receptor activation and $\mathrm{CB}_{1}$ receptor dependence in CFA-naïve mice. Mimicking the sustained treatment of Figure 2, we evaluated CB-13 for its potential to produce centrally mediated effects of $\mathrm{CB}_{1}$ receptor activation in nonCFA-treated mice. Otherwise naïve animals were administered CB-13 (3 and 10 mg/kg i.p.) or its vehicle and evaluated (in order) for catalepsy, tail-flick antinociception and hypothermia. The highest dose of CB-13 produced catalepsy on day 1 (A); however, by day 3 (B) and day 7 (C) 
this effect was no longer significant. The highest dose of CB-13 produced tail-flick antinociception on day 1 (D) but failed to do so on days $3(E)$ and $7(F)$, suggesting tolerance developed to this effect. Hypothermia was not induced on any day at any dose (G-I). Following a final injection of CB-13 on day 9, rimonabant (10 mg/kg i.p.) was administered to evaluate for the occurrence of $\mathrm{CB}_{1}$ receptor dependence. Similar to Figure 2, there was an increase in pawtremor $(\mathrm{J})$ and decrease in rimonabant-evoked scratching $(\mathrm{K})$ behaviors. ${ }^{*} \mathrm{P}<0.05$, ${ }^{* \star} \mathrm{P}<0.01$, ${ }^{\star * *} \mathrm{P}<0.001,{ }^{* \star *} \mathrm{P}<0.00012 \times 2$ ANOVA interaction effect. ${ }^{*} \mathrm{P}<0.05$, ${ }^{* \star *} \mathrm{P}<0.0001$ One-way ANOVA effect of treatment. Post-tests and other statistics are reported in Table S3. Data are expressed as mean \pm SEM. $\mathrm{N}=6-7$ per group. 
Figure 4
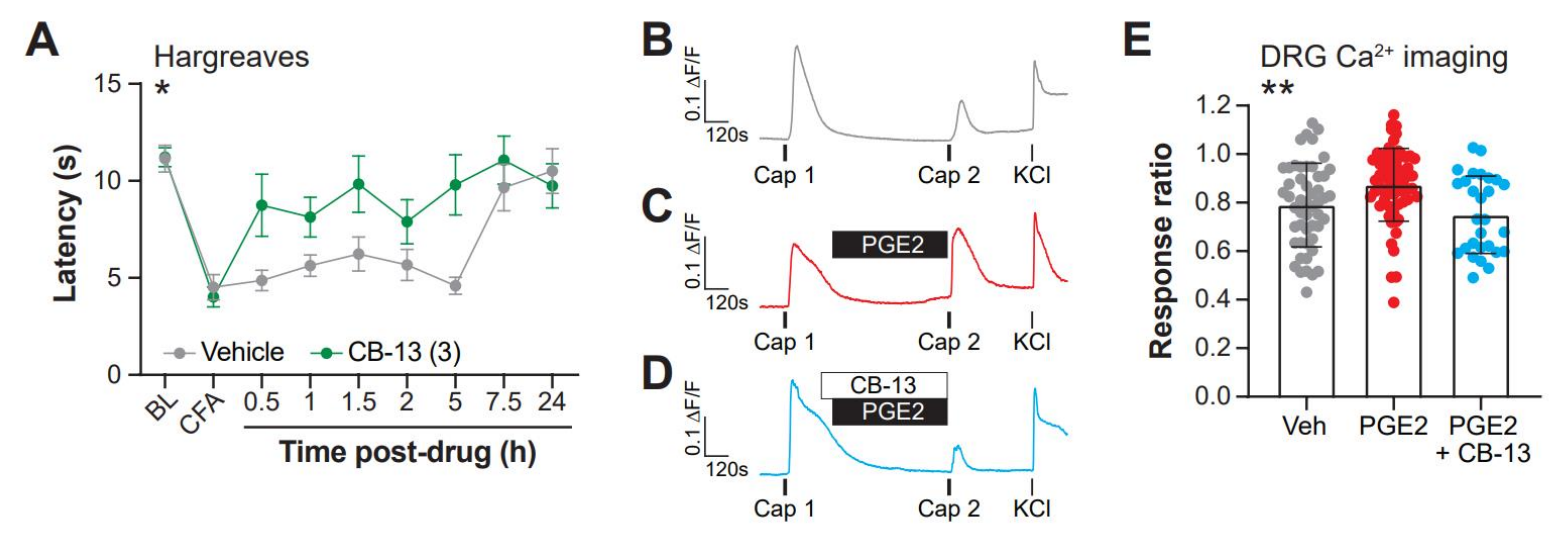

Figure 4. CB-13 reduces CFA-induced thermal allodynia and prevents PGE2-induced TRPV1 sensitization in mouse dorsal root ganglia neurons. CFA induces thermal allodynia ( $\mathrm{A}, \mathrm{BL}=$ baseline, $\mathrm{CFA}=25 \mathrm{hr}$ following CFA administration). CFA-induced thermal allodynia is reversed by administration of CB-13 $(3 \mathrm{mg} / \mathrm{kg}, \mathrm{A})$. The dose used here was maximally effective at reducing CFA-induced mechanical allodynia and was previously reported to be peripherally restricted[60]. To evaluate a potential mechanistic link to this finding, we evaluated the effect of CB-13 on TRPV1 sensitization induced by PGE2 in mouse dorsal root ganglia neurons.

Administration of capsaicin $(200 \mathrm{nM})$ results in calcium influx in isolated mouse DRG neurons. A second identical application of capsaicin leads to a reduced, or desensitized response $(B, E)$. This $2^{\text {nd }}$ capsaicin response is potentiated by application of the inflammatory mediator, PGE2 (1 $\mu M, B, E)$. This potentiation of the $2^{\text {nd }}$ capsaicin response by PGE2 is prevented by coapplication of CB-13 (1 $\mu \mathrm{M} ; \mathrm{D}, \mathrm{E}) .{ }^{*} \mathrm{P}<0.05 \mathrm{CB}-13$ vs. vehicle, $2 \times 2$ ANOVA interaction effect (A). ${ }^{*} \mathrm{P}<0.01$ One-way ANOVA. Post-tests and other statistics are reported in Table S4. Data are expressed as mean \pm SEM for $(A)$ and mean $\pm S D$ for $(E) . N=15$ mice per group $(A), N=$ 28-63 cells from 4-8 mice per condition (E). 
Figure 5
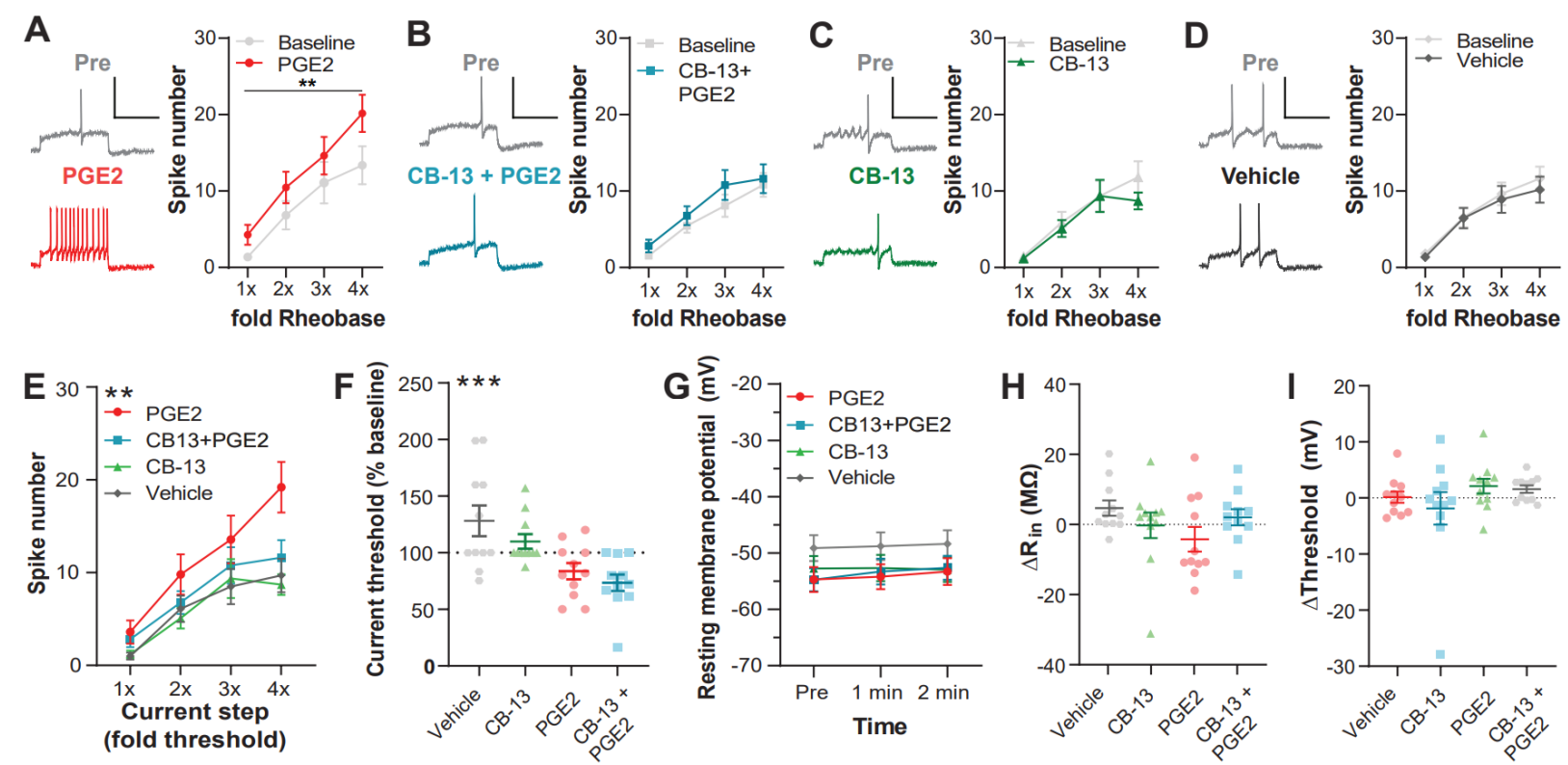

Figure 5. CB-13 attenuates PGE2-induced hyperexcitability of mouse DRG neurons in

vitro. (A-D) Action potential firing before (grey) and after drug treatment: $1 \mu \mathrm{M}$ PGE2 (A), $1 \mu \mathrm{M}$ CB-13+PGE2 (B), CB-13 alone (C) or vehicle (0.1\% DMSO; D). Right: Representative traces of action potentials at the minimum current threshold required to elicit an action potential (rheobase). Left: Input-output curve of number of action potentials evoked by depolarizing current injections, normalized to each cell's current threshold. PGE2 treatment led to an upward shift in the input-output curve compared to baseline. This effect was not seen in cells treated with both CB-13 and PGE2. CB-13 or vehicle, when applied alone, did not induce any changes in spike firing. (E) Input-output curve post-treatment for all drug groups. There was a significant effect of PGE2 treatment on spike firing, which was blocked by CB-13 co-treatment. (F) CB-13 did not block PGE2-induced decrease in the minimum current required to elicit an action potential. CB-13 or PGE2 had no effect on resting membrane potential $(\mathrm{G})$, input resistance $(\mathrm{H})$ or voltage threshold for an action potential $(\mathrm{I}) .{ }^{* *} \mathrm{P}<0.01$; Mixed effects model, main effect of treatment $(A, E) .{ }^{* * *} \mathrm{P}<0.001$; One-way ANOVA followed by Tukey post-hoc $(\mathrm{F}) . \mathrm{PGE} 2, \mathrm{~N}=11$ 
cells from 10 mice; $C B-13+P G E 2, N=11$ from 10 mice; $C B-13, N=11$ from 9 mice; Vehicle, $N$ = 11 from 8 mice. Post-tests and other statistics are reported in Table S5. Scale bars: $100 \mathrm{mV}$, $400 \mathrm{~ms}$. Data are expressed as mean \pm SEM. 